\title{
Hubungan konsumsi jajanan dan status karies gigi siswa di SMP NEGERI 1 Tareran
}

\author{
${ }^{1}$ Iwan P. Wawointana \\ ${ }^{2}$ Adrian Umboh \\ ${ }^{3}$ Paulina N. Gunawan
}

\author{
${ }^{1}$ Kandidat Skripsi Program Studi Pendidikan Dokter Gigi Fakultas Kedokteran \\ 2 Bagian Ilmu Kesehatan Anak Fakultas Kedokteran \\ ${ }^{3}$ Program Studi Pendidikan Dokter Gigi Fakultas Kedokteran \\ Universitas Sam Ratulangi Manado \\ Email: wawointana17@gmail.com
}

\begin{abstract}
Dental caries is caused by email and dentin demineralization. In general, school age children have a high caries risk because they like to consume cariogenic foods. This was a descriptive analytical study with a cross sectional approach. This study aimed to obtain the relationship between cariogenic food consumption and dental caries status among students of SMP Negeri 1 Tareran.The whole study population as many as 258 students were used as samples. Primary data consisted of the dental caries examination to obtain the number of dental caries status (DMF-T) and of the questionnaire by using Food Frequency Questionnaire (FFQ) to obtain the consumption of cariogenic foods. The results showed that cariogenic food consumption of the majority of students in SMP Negeri 1 Tareran was categorized as occasionally which meant several times weekly. Dental caries status of the students belonged to the low category with an average DMF-T 1,82 which meant each student had two caries teeth. The statistical test showed that there was a relationship between consumption of cariogenic food and dental caries status.
\end{abstract}

Keywords: consumption of cariogenic foods, dental caries status

\begin{abstract}
Abstrak: Karies gigi merupakan penyakit yang disebabkan oleh demineralisasi email dan dentin. Anak-anak usia sekolah umumnya berisiko tinggi terhadap karies karena mereka memiliki kebiasaan mengonsumsi makanan kariogenik. Penelitian ini menggunakan metode deskriptif analitik dengan pendekatan potong lintang. Penelitian ini bertujuan untuk mengetahui hubungan konsumsi jajanan dan status karies gigi di SMP Negeri 1 Tareran. Populasi penelitian yaitu seluruh murid di SMP Negeri 1 Tareran yang berjumlah 258. Sampel diambil dengan menggunakan metode total sampling. Pengambilan data primer yaitu pemeriksaan karies gigi untuk melihat status karies gigi (DMF-T) dan pengisian kuesioner dengan menggunakan Food Frequency Questionnaire (FFQ) untuk melihat konsumsi jajanan pada siswa di SMP Negeri 1 Tareran. Hasil penelitian menunjukkan bahwa konsumsi jajanan sebagian besar siswa SMP Negeri 1 Tareran termasuk dalam kategori kadang-kadang yakni beberapa kali dalam seminggu. Status karies gigi siswa SMP Negeri 1 Tareran termasuk dalam kategori rendah dengan rata-rata DMF-T 1,82 yang artinya siswa mengalami karies rata-rata 2 gigi. Hasil uji statistik yang dilakukan menunjukkan bahwa terdapat hubungan konsumsi jajanan dan status karies gigi.
\end{abstract}

Kata kunci: konsumsi jajanan, status karies gigi

Jajanan merupakan salah satu jenis makanan yang sangat dikenal dan umum di masyarakat, terutama anak usia sekolah. ${ }^{1}$

Anak-anak menyukai jajanan karena 
umumnya mengandung gula yang punya rasa manis. Keadaan demikian menyebabkan kebersihan gigi anak lebih buruk dibanding orang dewasa. ${ }^{2}$ Efek buruk dari seringnya mengkonsumsi makanan manis atau kariogenik yaitu terhadap kesehatan gigi. $^{3}$

Masalah yang sering ditemui dokter gigi ialah gigi berlubang. Gigi berlubang merupakan masalah klasik yang sejak dahulu sudah ada yang salah satu penyebab seseorang merasakan rasa sakit gigi. Gigi berlubang dapat dialami oleh semua orang yang masih hidup tidak mengenal usia orang tersebut. ${ }^{4}$

Gigi berlubang dapat disebabkan oleh keadaan gigi tersebut, makanan dan minuman yang dikonsumsi, keadaan dalam mulut yang melibatkan mikroorganisme dan waktu yang diperlukan sampai terjadinya gigi berlubang. Keadaan tersebut apabila dibiarkan terus menerus dapat menyebabkan gigi menjadi nekrosis. ${ }^{5}$

Kelompok yang rentan terkena masalah gigi berlubang yaitu anak-anak. Anak-anak rentan terkena masalah gigi berlubang karena sifat maupun sikap yang dimiliki anak-anak tersebut yang belum mengetahui tentang pentingnya menjaga keadaaan gigi tersebut. ${ }^{6}$

Berdasarkan keadaan tersebut penulis ingin meneliti status karies sehubungan dengan konsumsi jajanan kariogenik pada anak-anak di SMP Negeri 1 Tareran. Hal ini didukung juga SMP Negeri 1 Tareran berdasarkan hasil survei yang dilakukan tidak memiliki Usaha Kesehatan Gigi Sekolah (UKGS). SMP Negeri 1 Tareran juga belum pernah dilakukan penelitian mengenai karies dan penyuluhan kesehatan Gigi dan Mulut.

\section{BAHAN DAN METODE PENELITIAN}

Penelitian ini merupakan penelitian deskriptif analitik dengan pendekatan potong lintang yang dilakukan di SMP Negeri 1 Tareran. Teknik pengambilan sampel menggunakan teknik total sampling. Sampel penelitian ialah siswa yang bersekolah di SMP Negeri 1 Tareran yang berjumlah 258 siswa.
Instrumen penelitian yang digunakan yaitu kuesioner yang dipadukan dengan teknik wawancara serta menggunakan lembar pemeriksaan DMF-T.

Penilaian status karies dilakukan dengan menggunakan indeks DMF-T sedangkan Penilaian konsumsi jajanan didapatkan dengan cara pengisian food frequency questionnaire. Data dianalisis dengan menggunakan uji chi square.

\section{HASIL PENELITIAN}

Karakteristik responden dalam penelitian

Tabel 1. Karakteristik responden penelitian berdasarkan jenis kelamin

\begin{tabular}{lcc}
\hline \multicolumn{1}{c}{ Jenis Kelamin } & $\mathrm{n}$ & $\%$ \\
\hline Laki-laki & 95 & 45,90 \\
Perempuan & 112 & 54,10 \\
\hline Total & 207 & 100 \\
\hline
\end{tabular}

Tabel 2. Karakteristik responden penelitian berdasarkan usia

\begin{tabular}{lcc}
\hline Usia (Tahun) & $\mathrm{n}$ & $\%$ \\
\hline 12 & 83 & 40,10 \\
13 & 73 & 35,27 \\
14 & 44 & 21,25 \\
15 & 5 & 2,41 \\
16 & 2 & 0,97 \\
\hline Total & 207 & 100 \\
\hline
\end{tabular}

Tabel 3. Uji statistik konsumsi jajanan permen dan status karies gigi responden

\begin{tabular}{lllc}
\hline \multicolumn{4}{c}{ Chi-Square Tests } \\
\hline & Value & df & $\begin{array}{c}\text { Asymp. } \\
\text { Sig. (2- } \\
\text { sided) }\end{array}$ \\
\hline $\begin{array}{c}\text { Pearson Chi- } \\
\text { Square }\end{array}$ & $100,048^{\mathrm{a}}$ & 16 &, 000 \\
\hline $\begin{array}{c}\text { Likelihood } \\
\text { Ratio }\end{array}$ & 107,637 & 16 &, 000 \\
\hline $\begin{array}{c}\text { Linear-by- } \\
\text { Linear }\end{array}$ & 63,402 & 1 &, 000 \\
Association & 204 & \\
\hline $\begin{array}{c}\text { N of Valid } \\
\text { Cases }\end{array}$ & & \\
\hline $\begin{array}{l}\text { a. } 22 \text { cells (62,9\%) have expected count less than } \\
\text { 5. The minimum expected count is ,00. }\end{array}$ \\
\hline
\end{tabular}


Tabel 4. uji statistik hubungan konsumsi jajanan biskuit dan status karies gigi responden

\begin{tabular}{lccc}
\hline \multicolumn{4}{c}{ Chi-Square Tests } \\
\hline & Value & df & $\begin{array}{c}\text { Asymp. Sig. (2- } \\
\text { sided) }\end{array}$ \\
\hline $\begin{array}{c}\text { Pearson } \\
\text { Chi-Square }\end{array}$ & $17,492^{\mathrm{a}}$ & 16 &, 354 \\
\hline $\begin{array}{c}\text { Likelihood } \\
\text { Ratio }\end{array}$ & 19,602 & 16 &, 239 \\
\hline $\begin{array}{c}\text { Linear-by- } \\
\text { Linear }\end{array}$ & 2,248 & 1 &, 134 \\
$\begin{array}{l}\text { Association } \\
\text { N of Valid } \\
\text { Cases }\end{array}$ & 207 \\
\hline $\begin{array}{l}\text { a. } 12 \text { cells (48,0\%) have expected count less } \\
\text { than 5. The minimum expected count is ,07. }\end{array}$ \\
\hline
\end{tabular}

Tabel 5. Uji statistik hubungan konsumsi jajanan wafer dan status karies gigi responden

\begin{tabular}{lccc}
\hline \multicolumn{4}{c}{ Chi-Square Tests } \\
\hline & Value & Df & $\begin{array}{c}\text { Asymp. Sig. } \\
\text { (2-sided) }\end{array}$ \\
\hline $\begin{array}{l}\text { Pearson Chi- } \\
\text { Square }\end{array}$ & $34,267^{\mathrm{a}}$ & 16 &, 005 \\
\hline $\begin{array}{l}\text { Likelihood } \\
\text { Ratio }\end{array}$ & 31,914 & 16 &, 010 \\
\hline $\begin{array}{l}\text { Linear-by- } \\
\text { Linear } \\
\text { Association }\end{array}$ & 2,363 & 1 &, 124 \\
\hline $\begin{array}{l}\text { N of Valid } \\
\text { Cases }\end{array}$ & 207 & & \\
\hline
\end{tabular}

a. 11 cells (44,0\%) have expected count less than 5. The minimum expected count is, 08 .

Tabel 6. Uji statistik hubungan konsumsi jajanan cokelat dan status karies gigi responden

\begin{tabular}{lccc}
\hline \multicolumn{4}{c}{ Chi-Square Tests } \\
\hline & Value & Df & $\begin{array}{c}\text { Asymp. } \\
\text { Sig. (2- } \\
\text { sided) }\end{array}$ \\
\hline $\begin{array}{l}\text { Pearson Chi- } \\
\text { Square }\end{array}$ & $18,613^{\mathrm{a}}$ & 16 &, 289 \\
\hline Likelihood Ratio & 18,367 & 16 &, 303 \\
\hline $\begin{array}{l}\text { Linear-by-Linear } \\
\text { Association }\end{array}$ & 1,708 & 1 &, 191 \\
\hline N of Valid Cases & 207 \\
\hline $\begin{array}{l}\text { a. } 10 \text { cells (40,0\%) have expected count less than } \\
\text { 5. The minimum expected count is ,12. }\end{array}$ \\
\hline
\end{tabular}

Tabel 7. Uji statistik hubungan konsumsi jajanan gorengan dan status karies gigi responden

\begin{tabular}{llcc}
\hline \multicolumn{3}{c}{ Chi-Square Tests } \\
\hline & \multicolumn{3}{c}{$\begin{array}{c}\text { Asymp. } \\
\text { Sig. (2- } \\
\text { sided) }\end{array}$} \\
\hline $\begin{array}{l}\text { Pearson Chi- } \\
\text { Square }\end{array}$ & $20,054^{\mathrm{a}}$ & 16 &, 218 \\
\hline $\begin{array}{l}\text { Likelihood } \\
\text { Ratio }\end{array}$ & 18,548 & 16 &, 293 \\
\hline $\begin{array}{l}\text { Linear-by- } \\
\text { Linear } \\
\text { Association }\end{array}$ &, 001 & 1 &, 971 \\
\hline $\begin{array}{l}\text { N of Valid } \\
\text { Cases }\end{array}$ & 207 & & \\
\hline $\begin{array}{l}\text { a. } 16 \text { cells (64,0\%) have expected count less than } \\
\text { 5. The minimum expected count is ,04. }\end{array}$ \\
\hline
\end{tabular}

Tabel 8. Uji statistik hubungan konsumsi jajanan miedal dan status karies gigi responden

\begin{tabular}{lccc}
\hline \multicolumn{3}{c}{ Chi-Square Tests } \\
\hline & Value & df & $\begin{array}{c}\text { Asymp. } \\
\text { Sig. (2- } \\
\text { sided) }\end{array}$ \\
\hline $\begin{array}{l}\text { Pearson Chi- } \\
\text { Square }\end{array}$ & $21,549^{\mathrm{a}}$ & 16 &, 158 \\
\hline $\begin{array}{l}\text { Likelihood } \\
\text { Ratio }\end{array}$ & 27,625 & 16 &, 035 \\
\hline $\begin{array}{l}\text { Linear-by- } \\
\text { Linear } \\
\text { Association }\end{array}$ & 2,628 & 1 &, 105 \\
\hline $\begin{array}{l}\text { N of Valid } \\
\text { Cases }\end{array}$ & 207 & & \\
\hline
\end{tabular}

a. 12 cells $(48,0 \%)$ have expected count less than 5. The minimum expected count is, 07 .

Tabel 9. Uji statistik hubungan konsumsi jajanan bakso dan status karies gigi responden

\begin{tabular}{lccc}
\hline \multicolumn{3}{c}{ Chi-Square Tests } \\
\hline & Value & df & $\begin{array}{c}\text { Asymp. } \\
\text { Sig. (2- } \\
\text { sided) }\end{array}$ \\
\hline $\begin{array}{l}\text { Pearson Chi- } \\
\text { Square }\end{array}$ & $21,755^{\mathrm{a}}$ & 16 &, 151 \\
\hline $\begin{array}{l}\text { Likelihood } \\
\text { Ratio }\end{array}$ & 21,015 & 16 &, 178 \\
\hline $\begin{array}{l}\text { Linear-by- } \\
\text { Linear } \\
\text { Association }\end{array}$ & 321 & 1 &, 571 \\
\hline $\begin{array}{l}\text { N of Valid } \\
\text { Cases }\end{array}$ & 207 & & \\
\hline $\begin{array}{l}\text { a. } 12 \text { cells (48,0\%) have expected count less than } \\
\text { 5. The minimum expected count is ,07. }\end{array}$ \\
\hline
\end{tabular}




\section{BAHASAN}

Penelitian ini dilakukan pada 207 siswa dengan karakteristik yang dikelompokan berdasarkan jenis kelamin dan usia. Jumlah siswa laki-laki sebanyak 95 orang $(45,90 \%)$ dan siswa perempuan sebanyak 112 orang (54,10\%). Subjek penelitian terdiri dari usia 12 sampai 16 tahun. Jumlah siswa 12 tahun sebanyak 83 orang (40,10\%), 13 tahun sebanyak 73 orang $(35,27 \%), 14$ tahun sebanyak 44 orang (21,25\%), 15 tahun sebanyak 5 orang $(2,41 \%)$ dan 16 tahun sebanyak 2 orang $(0,97 \%)$.

Berdasarkan hasil pemeriksaan konsumsi jajanan didapatkan yang mengonsumsi jajanan permen beberapa kali seminggu atau kadang-kadang memiliki presentase paling tinggi yaitu 44,92\%, sedangkan konsumsi jajanan yang paling rendah yaitu 1 kali sebulan atau kategori tidak pernah mengonsumsi jajanan permen yaitu 1,45\%. Pada konsumsi jajanan biskuit yang paling tinggi yaitu mengonsumsi beberapa kali seminggu atau kadangkadang sebesar 38,65\% dan paling rendah sebesar 7,24\% yaitu hampir tidak pernah atau 1 kali seminggu. Konsumsi jajanan wafer yang paling tinggi yaitu beberapa kali seminggu atau kadang-kadang sebesar 44,92\% dan paling rendah yaitu 1 kali seminggu atau hampir tidak pernah sebesar 7,72\%.

Konsumsi jajanan cokelat beberapa kali seminggu atau kadang-kadang menempati urutan paling tinggi sebesar 40,58\% sedangkan yang paling rendah yaitu 1 kali sebulan atau tidak pernah sebesar 12,08\%. Konsumsi jajanan gorengan paling tinggi yaitu satu kali sehari atau sering sebesar 32,36\% dan paling rendah yaitu 1 kali seminggu atau hampir tidak pernah sebesar 1,45\%. Pada konsumsi jajanan miedal yang paling tinggi yaitu beberapa kali seminggu atau kadangkadang sebesar 36,23\% dan yang paling rendah yaitu lebih dari 2 kali sehari atau sangat sering sebesar 6,76\%. Konsumsi jajanan bakso paling tinggi yaitu beberapa kali seminggu atau kadang-kadang sebesar $43 \%$ dan paling rendah yaitu lebih dari 2 kali sehari atau sangat sering sebesar
8,21\%.

Penelitian ini hampir serupa dengan hasil penelitian Meishi di Medan tahun 2011 yang menunjukkan bahwa banyak responden yang mengonsumsi jajanan berpotensi tinggi dan sedang menyebabkan karies. Umumnya jajanan yang berpotensi tinggi menyebabkan karies seperti permen, cokelat, keripik, kue, biskuit, wafer dan jajanan berpotensi sedang menyebabkan karies seperti minuman manis, bakso, kerupuk, dan goreng-gorengan merupakan jajanan yang selalu disediakan di kantin sekolah dengan harga yang dapat dijangkau oleh anak sekolah, karena rasanya enak dan dapat memberi rasa kenyang sehingga disukai anak-anak. ${ }^{24}$

Hasil pemeriksaan karies berdasarkan indeks DMF-T pada 207 siswa di SMP Negeri 1 Tareran menunjukkan DMF-T rata-rata sebesar 1,82. Berdasarkan kategori indeks karies menurut WHO termasuk dalam kategori rendah.

Analisis uji statistik pada penelitian ini terdiri dari tujuh jenis analisis hubungan konsumsi jajanan dan status karies dan dibagi berdasarkan jumlah jajanan yang penulis bahas dalam penelitian ini. Analisis data diuji menggunakan uji statistik chisquare. Berdasarkan tujuh jenis jajanan, terdapat dua jenis jajanan yaitu permen dan wafer memiliki hubungan yang bermakna dan status karies gigi.

Hasil analisis uji statistik tentang konsumsi jajanan permen, wafer dan status karies gigi didapatkan ada hubungan antara konsumsi jajanan dan status karies gigi. Penelitian ini hampir serupa dengan hasil penelitian dari Meishi di Medan tahun 2011 yaitu terdapat hubungan jajanan berpotensi tinggi dan sedang penyebab karies dengan pengalaman karies. DMF-T meningkat apabila frekuensi mengonsumsi jajanan tinggi sebaliknya menurun pada frekuensi konsumsi yang jarang atau tidak pernah sama sekali. ${ }^{7}$ Hasil penelitian Jazzalina di Medan tahun 2011 menunjukkan terdapat perbedaan yang signifikan antara jajanan berpotensi tinggi, sedang, rendah dengan pengalaman karies. Pengalaman karies lebih tinggi pada responden yang 
mengonsumsi jajanan kariogenik berpotensi tinggi menyebabkan karies dengan frekuensi sangat sering. ${ }^{8}$

Hasil penelitian menunjukkan bahwa kue, snack cokelat, dan permen dikonsumsi oleh lebih dari 50\% subjek penelitian. Penelitian ini menunjukkan bahwa konsumsi kedua jajanan dan status karies gigi memiliki hubungan. Hasil yang berbeda pada konsumsi jajanan cokelat, gorengan, miedal, bakso dan biskuit menunjukkan tidak terdapat hubungan berdasarkan uji statistik.

Beberapa konsumsi jajanan dan status karies gigi yang tidak memiliki hubungan yaitu gorengan, miedal dan bakso. Tingkat kariogenitas oleh jenis makanan ini sangatlah tinggi tetapi frekuensi konsumsi yang rendah mempengaruhi status karies gigi. $^{9}$

Frekuensi mengonsumsi merupakan salah satu kontributor yang signifikan terhadap diet makanan. Frekuensi sangat mempengaruhi proses demineralisasi dan remineralisasi. ${ }^{10}$ Asam yang terbentuk oleh jajanan akan menurunkan $\mathrm{pH}$ rongga mulut sehingga terjadi suasana asam dan dampaknya yaitu proses demineralisasi. Proses demineralisasi akan menyebabkan email gigi kehilangan ion kristalisasi sehingga keterpaparan gigi sangatlah tinggi. $^{11}$ Frekuensi konsumsi jajanan yang sangat tinggi menyebabkan lebih banyak proses demineralisasi dibandingkan remineralisasi. Ketidakseimbangan antara proses demineralisasi dan remineralisasi menyebabkan terjadinya karies. ${ }^{12}$

\section{SIMPULAN}

1. Konsumsi jajanan di SMP Negeri 1 Tareran sebagian besar termasuk kategori kadang-kadang .

2. Status karies gigi di SMP Negeri 1 Tareran tergolong rendah.

3. Terdapat hubungan dua dari 7 jenis konsumsi jajanan yaitu permen dan wafer dengan status karies gigi di SMP Negeri 1 Tareran.

\section{SARAN}

1. Bagi pemerintah desa Rumoong Atas dua disarankan untuk meningkatkan program promotif dan preventif di bidang kesehatan khususnya kesehatan gigi dan mulut.

2. Bagi masyarakat khususnya orang tua disarankan untuk menjalankan program preventif untuk meningkatkan derajat kesehatan gigi dan mulut.

3. Bagi sekolah disarankan untuk menjalankan Usaha Kesehatan Gigi Sekolah (UKGS) dalam upaya promotif dan preventif guna peningkatan kesehatan gigi dan mulut serta mengurangi penjualan permen dan wafer.

\section{UCAPAN TERIMA KASIH}

Ucapan terima kasih disampaikan pada drg. Michael A. Leman, MMedEd, drg. Chisty N. Mintjelungan, M.Kes serta semua pihak yang baik secara langsung maupun tidak langsung telah menumbuhkan ide atau gagasan dalam penulisan ini.

\section{DAFTAR PUSTAKA}

1. Andriyani A, Hastuti S. Perbedaan Pengaruh Pendidikan Kesehatan Gigi dalam Meningkatkan Tentang Kesehatan Gigi pada Anak di SD Negeri 2 Sambi Kecamatan Sambi Kabupaten Boyolali. Gaster. 2010;7(2):624-32.

2. Wahyono B, Tunggal E, Nurhidayat $O$. Perbandingan Media Power Point dengan Flip Chart dalam Meningkatkan Pengetahuan Kesehatan Gigi dan Mulut. Unnes Journal of Public Health. 2012;1(1):31-5.

3. Hana YK, Nuryanto. Hubungan kejadian karies gigi dengan konsumsi makanan kariogenik dan status gizi pada anak sekolah dasar. Journal of Nutrition College. 2014;3(3):414-21.

4. Hidayanti L. Hubungan karakteristik keluarga dan kebiasaan konsumsi makanan kariogenik dengan keparahan karies gigi anak sekolah dasar. Semarang: November 2005. Available from URL: http://eprints.undip.ac.id/8535/1/LILI K.pdf.

5. Prasetyo AE. Keasaman minuman ringan 
menurunkan kekerasan permukaan gigi. Dent J. 2005;38(2):60-3.

6. Angela A. Pencegahan primer pada anak beresiko karies tinggi. Maj Ked Gigi. 2005;38(3):130-4.

7. Meishi PRL. Hubungan Tingkat Konsumsi Makanan Kariogenik Dengan Karies Gigi Pada Anak Sekolah Dasar Swasta Muhammadiyah 08 Medan [Skripsi]. Medan: Universitas Sumatera Utara; 2011. (diakses agustus 2015). Tersedia dalam URL: http://repository.usu.ac.id/handle/123 456789/30865.

8. Jamil JA. Hubungan antara Kebiasaan Mengonsumsi Jajanan dengan Pengalaman Karies pada Gigi Susu Anak Usia 4-6 Tahun di TK Medan [Skripsi]. Medan: Universitas Sumatera Utara; 2011. (diakses
Agustus 2015). Tersedia dalam URL: http://repository.usu.ac.id/handle/123 456789/30865.

9. Touger R, Loveren CV. Sugars and dental caries. Am J clin nutr. 2003;78:8815925.

10.Moynihan PJ. The Role of diet and nutrion in the etiology and prevention of oral diseases. Bulletin of the World Health Organization. 2005;(83):694-9

11.Moynihan PJ , Petersen PE. Diet, nutrition and the prevalention of the dental diseases. Public Health Nutrition 2007;(1):201-6.

12.Lame AFP, KH, kooBellato CM, BG, Cury JA. The role of sucrose in cariogenic dental biofilm formation new insight. J Dent Res. 2006;85 (10):878-87. 